Chirurgia (2018) 113: 611-624

No. 5, September - October

Copyright $\odot$ Celsius

http://dx.doi.org/10.21614/chirurgia.113.5.611

\title{
Surgical Complications of Peritoneal Dialysis
}

\author{
Octavian Mihalache ${ }^{1,2}$, Horia Dorann ${ }^{1,2}$, Petronel Mustățea ${ }^{1,2}$, Florin Bobircăa ${ }^{1,2}$, Dragoș Georgescu ${ }^{1,2}$, \\ Andra Bîrligea ${ }^{2}$, Alexandra Agache ${ }^{1,2}$, Traian Pătrașcu ${ }^{1,2}$ \\ 1"Carol Davila" University of Medicine and Pharmacy, Bucharest, Romania \\ 2"I Juvara" Department of Surgery, "Dr. I. Cantacuzino" Clinical Hospital, Bucharest, Romania
}

Corresponding author: Associate Professor Horia Doran "Carol Davila" University of Medicine and Pharmacy

"Dr. I. Cantacuzino" Clinical Hospital 1st Surgical Department

E-mail: doranh2003@yahoo.com
Received: 09.07.2018 Accepted: 07.09.2018

\section{Rezumat \\ Complicatiile chirurgicale ale dializei peritoneale}

Dializa peritoneală este o metodă de substitutie a functiei renale cu mai multe avantaje precum autonomia pacientului, mai puține prezentări la spital şi conservarea funcției renale reziduale, dar care are şi dezavantaje. Acestea sunt în principal durata limitată în timp a terapiei determinată de alterarea membranei peritoneale şi riscul infecțios. Cea mai importantă complicație a dializei peritoneale rămâne peritonita, care este responsabilă în cele mai multe cazuri de eşecul metodei. Mai sunt şi alte complicații, care incorect tratate pot duce de asemenea, la eşecul metodei: complicatii mecanice, defecte parietale, infectii ale tunelului subcutanat sau ale breşei de exteriorizare. Scleroza peritoneală încapsulantă este o entitate rară asociată dializei peritoneale, dar cu morbiditate si mortalitate crescute. Am analizat retrospectiv pacientii cu insuficiență renală cronică în stadiul V tratați prin dializă peritoneală, care au fost internați în Clina de chirurgie „I. Juvara” a Spitalului Clinic „Dr. I. Cantacuzino” înperioada 2007-20017 pentru complicații ale dializei peritoneale. Aceşti pacienți au fost împărțiți în două grupuri: complicații neinfecțioase şi infecțioase. Am identificat 109 pacienți care au suferit 126 de intervenții chirurgicale pentru complicații ale dializei peritoneale. Dintre acestea 30 de intervenții au fost extrageri de cateter pentru pierderea capacității de ultrafiltrare, aceşti pacienți au fost excluşi din analiză. Lotul rezultat a constat în 80 de pacienți cu 91 de complicații: 42 neinfecțioase şi 49 infecțioase. Vârsta medie a fost de $60,5( \pm 12.3)$ ani cu o distributie bărbati/femei de 2,75/1. Diabetul zaharat a fost prezent la $45(56,25 \%)$ dintre pacienți. Comparând cele două grupuri am găsit asocieri semnificative în ceea ce priveşte durata perioadei de dializă peritoneală şi tipul 
complicațiilor, în sensul debutului mai tradiv al complicațiilor infecțioase față de cele neinfecțioase. De asemenea pierderea metodei de dializă ca şi consecință a complicațiilor are o puternică asociere cu cele infecțioase. În interiorul grupurilor am constatat că defectele parietale se asociază cu antecedentele personale de intervenții chirurgicale abdominale $(p<0,001)$. In ceea ce priveşte morbiditatea şi mortalitatea, doar cei din grupul complicațiilor infecțioase au avut mortalitate asociată, morbiditatea nefiind diferită între cele două grupuri. Între aceşti pacienți am identificat şi 16 cu scleroză peritoneală încapsulantă. Aceasta a fost diagnosticată în cele mai multe cazuri în timpul intervenției pentru o alta complicație. La aceşti pacienți a fost înregistrată o mortalitate de $20 \%$. În concluzie, complicațile neinfecțioase nu ridică probleme majore de diagnostic şi tratament, dar incorect tratate pot duce la eşecul metodei. Complicațiile infecțiose, în special peritonita, rămân principala cauză de eşec al metodei. Dintre toate, acestea generază cele mai mari rate de morbiditate şi mortalitate la pacienții dializați peritoneal. Chiar dacă intervenția chirurgicală de urgență nu este de obicei necesară pentru peritonitele asociate dializei peritoneale, observația chirurgicală este întotdeuna obligatorie. Scleroza peritoneală încapsulantă este o complicație rară, dar severă a dailizei peritoneale. Riscul de apariție al acesteia creşte cu durata utilizării dializei peritoneale. $\mathrm{Nu}$ au fost descoperite teste de screening utile, în special pentru stadiile incipiente. De aceea, este important ca semnele clinice să nu fie subestimate, diagnosticul fiind bazat pe un grad înalt de suspisiune ridicată de acestea. Singurul tratament consacrat este liza aderențelor peritoneale de aceea timpul nu trebuie irosit pe tratamentul conservator.

Cuvinte cheie: dializă peritoneală, cateter, peritonită, scleroză peritoneală încapsulantă

\begin{abstract}
Peritoneal dialysis (PD) is a method of renal function replacement which has a series of advantages like greater autonomy of the patient with fewer hospital visits and better preservation of residual renal function, but it has also disadvantages. The main disadvantages are a limited life-time due to peritoneal membrane failure and the risk of infections. The main complication of PD remains peritonitis, which is responsible for the most cases of method failure. There are also other complications which incorrect treated may lead to failure of the method: mechanical complications, abdominal wall defects, exit site and tunnel infections. Encapsulating peritoneal sclerosis is a rare entity found in PD patients but with high morbidity and mortality. We have retrospectively analyzed the patients with end stage renal disease under peritoneal dialysis which were admitted to Surgical Clinic "I. Juvara" of the Clinical Hospital "Dr. I. Cantacuzino" between 2007 and 2017 for surgical complications related to PD. The patients were assigned in two groups: with non-infectious and infectious complications. We have found 109 patients which have had 126 surgical interventions related to peritoneal dialysis. Out of these, 30 interventions consisted in catheter removal for loss of ultrafiltration capacity, so these were excluded from analysis. The lot resulted consisted in 80 patients with 91 complications: 42 non-infectious and 49 infectious. Mean age was 60.5 ( \pm 12.3 ) years. Sex distribution was $2.75 / 1$ male/female. Diabetes mellitus was present at $45(56,25 \%)$ patients. Comparing the patients with non-infectious with those with infectious complications we found significant association between type of complications and the length of PD in the sense that infectious complications tend to appear later than the non-infectious. Also, the loss of peritoneal dialysis is strongly associated with infectious complications. Looking inside groups we found that abdominal wall defects are associated with the history of previous abdominal surgery $(p<0,001)$. Regarding the morbidity and mortality only infectious complications had associated mortality in our study, there were no significant differences in morbidity rate between groups. Between all these patients we have also identified 16 with encapsultating peritoneal sclerosis. In most cases the diagnosis was established during the intervention for another complication. We have registered a $20 \%$ morality rate at these patients. Conclusions: Noninfectious surgical complications are not raising problems for diagnosis or surgical treatment, but an incorrect treatment may lead to failure
\end{abstract}


of the PD. Infectious complications and especially peritonitis remains the main cause of method failure. These are generating the highest rates of morbidity and mortality from peritoneal dialysis complications. Even if the immediate surgical intervention for peritonitis related to peritoneal dialysis is usually unnecessary, surgical observation is absolutely mandatory in every case. The absence of a response to the proper medical treatment is an indication for peritoneal cavity exploration inclusive by laparoscopy/laparotomy. Any delay in diagnosis and definitive treatment can lead to loss of peritoneal membrane function and even death of the patient. Encapsulated peritoneal sclerosis is a rare but serious complication of PD. The risk for developing EPS increases with the duration of PD treatment. No predictive and reliable screening tests especially in the early stages of EPS were found. So, it is important not to underestimate the clinical symptoms, diagnosis being based on a high index of suspicion. The only established basic treatment of EPS is enterolysis of peritoneal adhesions, and time should not be unnecessarily wasted on conservative treatment.

Key words: peritoneal dialysis, catheter, peritonitis, encapsulted peritoneal sclerosis

\section{Introduction}

Chronic kidney disease is a condition with rising incidence and prevalence and it represents an important public health problem worldwide due to high associated morbidity and mortality and also to high costs of treatment. Diabetes mellitus is the main cause of renal failure accounting for about $45 \%$ of all new cases. Diabetic nephropathy affects $25-35 \%$ of patients under 30 years old and also chronic kidney failure is the main cause of death in young diabetic patients (1).

Peritoneal dialysis (PD) is a method of renal function replacement used in end stage renal disease along with hemodialysis and renal transplantation. It has a series of advantages like low mortality rate in the first year, greater autonomy, flexibility, fewer hospital visits and better preservation of residual renal function. The main disadvantages of petrioneal dilaysis are the risk of infections and a limited life-time due to the peritoneal membrane failure (2).

Presence of a permanent catheter in the peritoneal cavity is similar with a chronic peritoneal fistula which exposes the patient to a series of complications. Some of these complications require surgical treatment. Surgical complications of PD may be classfied as infectious and non-infectious. Infectious complications are represented by peritonitis, exit-site and tunnel infections. Non-infectious complications are mechanical like catheter obstruction or malfunction, external leakage, abdominal wall deffects, scrotal swelling, pleuro-peritoneal fistula, ultrafiltration failure and encapsulated peritoneal slcerosis (3).

The majority of catheter related problems are of an infectious nature. PD complications are mainly represented by peritonitis (61\%), exit-site and tunnel infections (23\%), leakage and mechanical complications like obstruction and dislocation are making up the rest (4).

Infectious complications are generating increased morbidity and mortality being the main cause of failure in PD. Peritonitis remains the leading complication having around 18\% of the infection-related mortality in PD patients. Although less than $5 \%$ of peritonitis episodes result in death, peritonitis is a "contributingfactor" in 16\% of deaths on PD (5).

Encapsulating peritoneal sclerosis (EPS) is another of the potential complications of longterm PD. It is associated with high morbidity related to bowel obstruction and malnutrition. The reported mortality of this condition is around 50\%, usually within 12 months of the diagnosis. Evidence-based guidelines on EPS are faceing some difficulties caused by: the lack of well-defined diagnostic criteria, especially to early stages of EPS; the lack of interventions that consistently improve the 
outcome, the fact that EPS may develop or symptomatically progress after discontinuation of PD and transfer to $\mathrm{HD}$ or transplantation, making guidance about when to transfer patients electively from PD to HD particularly difficult (6).

\section{Material and Methods}

We have retrospectively analyzed the patients with end stage renal disease under peritoneal dialysis which were admitted to Surgical Clinic "I. Juvara" of the Clinical Hospital "Dr. I. Cantacuzino" between 2007 and 2017 for surgical complications related to PD. The patients were assigned in two groups: with non-infectious and infectious complications.

We compared the two groups in search of possible risk factors and significant differences regarding age, sex, education, peritoneal dialysis duration, comorbidities, remaining diuresis, PD failure causes, postoperative morbidity and mortality.

For the statistic analysis we used SPSS1.0.0.1126 and Microsoft Excell 2007.

\section{Results}

We have found 109 patients which have had 126 surgical interventions related to peritoneal dialysis. Out of these, 30 interventions consisted in catheter removal for loss of ultrafiltration capacity, so these were excluded from analysis. The lot resulted consisted in 80 patients with 91 complications: 42 non-infectious and 49 infectious. Mean age was 60.5 $( \pm 12.3)$ years. Sex distribution was 2.75 male to 1 female. Diabetes mellitus was present at $45(56,25 \%)$ patients. Detailed types of complications are presented in Table 1. Peritonitis represented $43.9 \%$ of all complications. In 16 cases encapsulated peritoneal sclerosis was found.

\section{Non Infectious Complications}

These types of complications were represented by mechanical complications, abdominal wall defects and in 2 cases a pseudo-hydrocele and a subcutaneous peritoneal fistula manifested by an abdominal wall edema.

Mechanical complications were the second frequent type of complication which had been found in 22 patients. Catheter blockage was the main cause of malfunction in 16 patients (14 cases by the great omentum and in 2 female cases by one of the fallopian tube (Fig. 1), the rest presented a mobilization of the catheter's tip. 5 patients had associated complications: 2 external peritoneal fistula, 1 a pleuro-peritoneal fistula, 1 a pseudo hydrocele and 1 an incisional hernia. The time from initiation of PD to complication was between 1 and 4 weeks for 15 out of 22 patients (median 4, range 1to 88). Surgical interventions consisted in unblocking, repositioning and fixing of the catheter to the anterior abdominal wall. In two cases a replacement of the catheter was needed: one due to an external peritoneal fistula and the other had an incisional hernia. In one case with extensive intraperitoneal adhesions the catheter was removed and PD interrupted.

Abdominal wall defects were found in $18(19.8 \%)$ patients and were represented by

Table 1. Types and number of peritoneal dialysis complications

\begin{tabular}{llc}
\hline & Peritoneal dialysis complications & N (\%) \\
\hline Infectious & Peritonitis & $40(43,9 \%)$ \\
\cline { 1 - 2 } & Exit-site and subcoutaneus tunnel infections & $9(9,9 \%)$ \\
\hline Non-infectious & Mechanical (obstruction, mobilisation of the catheter) & $22((24,2 \%)$ \\
\hline & Abdominal wall defects & $18(19,9 \%)$ \\
\hline & Subcutaneous peritoneal fistula & $1(1,1 \%)$ \\
\hline Encapsultaing peritoneal sclerosis & Pseudo hydrocele & $1(1,1 \%)$ \\
\hline
\end{tabular}




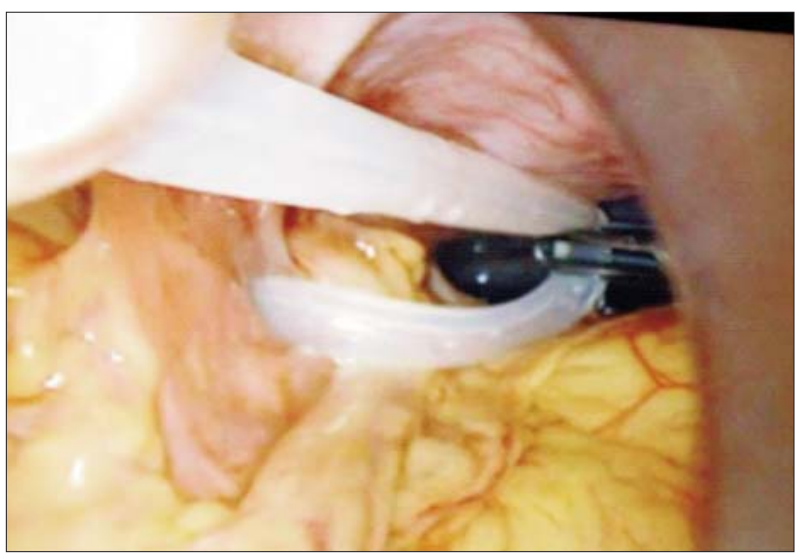

Figure 1. Catheter obstruction due to omental wraping

inguinal hernias (7 cases), umbilical hernias (6 cases) and incisional hernias (5 cases). Sex ratio $\mathrm{B} / \mathrm{F}$ was 3.5/1.Median interval from the start of $\mathrm{PD}$ to diagnosis was 12 months (range 1 to 48). Surgical treatment consisted in a tension free procedure using a polypropylene mesh in 10 cases and an anatomical tissue repair in the rest of 8 cases. In two cases incarceration was present; both had also associated encapsulating peritoneal sclerosis. For these patients catheter removal was also necessary, PD being discontinued. Removal of the catheter was performed in another patient with ultrafiltration failure.
Postoperatively there were no significant complications, all patients excepting the 3 in which catheter was removed, continued PD.

In the case of the patient with pseudo-hydrocele ligation and resection of the peritoneovaginal canal with recalibration of the internal inguinal ring was performed, and in the other case with the subcutaneous peritoneal fistula the catheter was replaced.

Overall no mortality was registered for the patients with non-infection complications. There were 4 cases with postoperative complications: 1 wound infection, 1 external peritoneal fistula, 1 peritoneo-pleural fistula and one with cardiac complications. All were treated conservatively. Also in 4 patients the catheter was removed and PD discontinued.

\section{Infectious Complications}

Infectious complications were represented in their vast majority by peritonitis $(81.6 \%)$ the rest were infections of the exit-site or subcutaneous tunnel (18.4\%). The types of peritonitis according to ISPD (International Society of Peritoneal Dialysis) terminology (Table 2) and their etiology are figurate in Table 3. 5 cases may be also classified as catheter - related

Table 2. Peritonitis terminology

\begin{tabular}{|c|c|}
\hline Recurrent & An episode that occurs within 4 weeks of completion of therapy of a prior episode but with a different organism \\
\hline Relapsing & $\begin{array}{l}\text { An episode that occurs within } 4 \text { weeks of completion of therapy of a prior episode with the same organism or } \\
1 \text { sterile episode }\end{array}$ \\
\hline Repeat & An episode that occurs more than 4 weeks after completion of therapy of a prior episode with the same organism \\
\hline Refractory & Failure of the effluent to clear after 5 days of appropriate antibiotics \\
\hline $\begin{array}{l}\text { Catheter-related } \\
\text { peritonitis }\end{array}$ & Peritonitis in conjunction with an exit-site or tunnel infection with the same organism or 1 site sterile \\
\hline
\end{tabular}

Table 3. Microorganisms identified and types of peritonitis

\begin{tabular}{lccc}
\hline Type of peritonitis & & Relapsing \\
\hline Etiology & Refractory & 3 & Recurrent \\
\hline Bacterial & 7 & 0 & 0 \\
\hline Fungal & 10 & 4 & 3 \\
\hline Sterile & 7 & 4 & 2 \\
Without microbiological culture & 28 & 10 & 2 \\
\hline Total & & 0 & \\
\hline
\end{tabular}


peritonitis as they were associated with exitsite or tunnel infections. The most frequent microorganisms identified were fungi (candida albicans in 9 patients and aspergilus in 1 case) followed by staphylococcus aureus in 4 cases, pseudomonas and enterobacter in 2 cases, streptococcus beta hemolytic and klebsiella in 1 case each. In 7 cases the microbiological cultures remained sterile. In 10 cases an encapsulated peritoneal sclerosis was revealed (Fig. 2). The main indication for catheter removal and surgical exploration was refractory peritonitis due to fungal or bacterial infection (70\%) followed by relapsing peritonitis and recurrent peritonitis in $25 \%$ and respectively $5 \%$.

Surgical interventions consisted in simple catheter removal for patients with no clinical sings of peritonitis or for those with fungal peritonitis - 13 cases. For two patients replacement of the catheter was performed. For the rest additional gestures were required like exploration of the peritoneal cavity, adhesiolysis, peritoneal lavage and drainage.

Infections of the exit-site and subcutaneous tunnel were found in 9 patients. 3 cases were closely related to a mobilization of the external cuff (Fig. 3). Catheter removal was performed in 2 cases, 3 cases benefit of a two stage replacement of the catheter (initial removal an reinsertion after a few days) and in the remained 4 cases a surgical drainage of the tunnel while keeping the catheter in place was performed (Fig. 4).

From all infectious complications in 40 (81.6\%) patients the catheter was removed and PD was interrupted. Only 9 (18.4\%) patients remained on PD.

Postoperatively were 6 (12\%) patients with complications of which $3(6 \%)$ died. One patient developed a postoperative bowel obstruction which needed reintervention with favorable evolution afterwards, one patient had a mechanical malfunction of the catheter which was solved by laparoscopic reposition of the catheter and one developed a Clostridium Difficile colitis solved by specific antibiotic therapy. From the patients who died one developed an upper gastrointestinal bleeding followed by respiratory insufficiency, and the

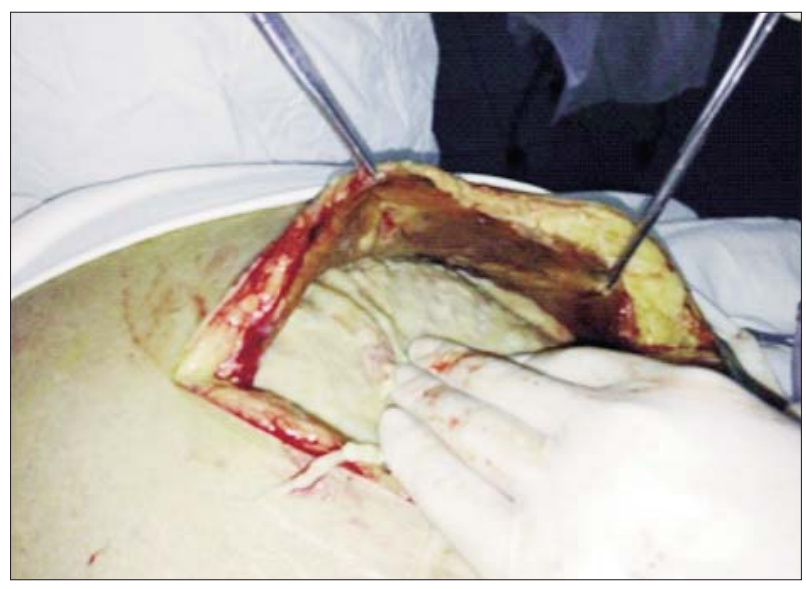

Figure 2. Intraoperative aspect of an advanced EPS associated with peritonitis

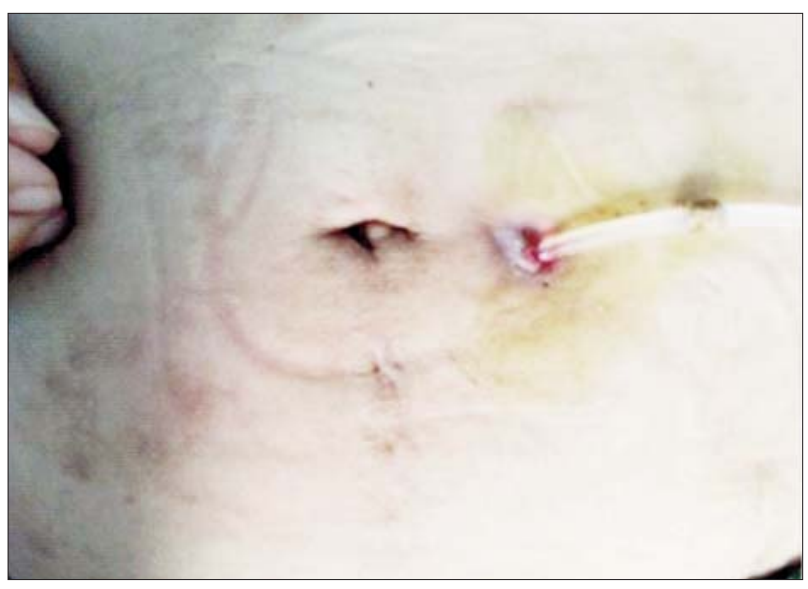

Figure 3. External cuff mobilisation

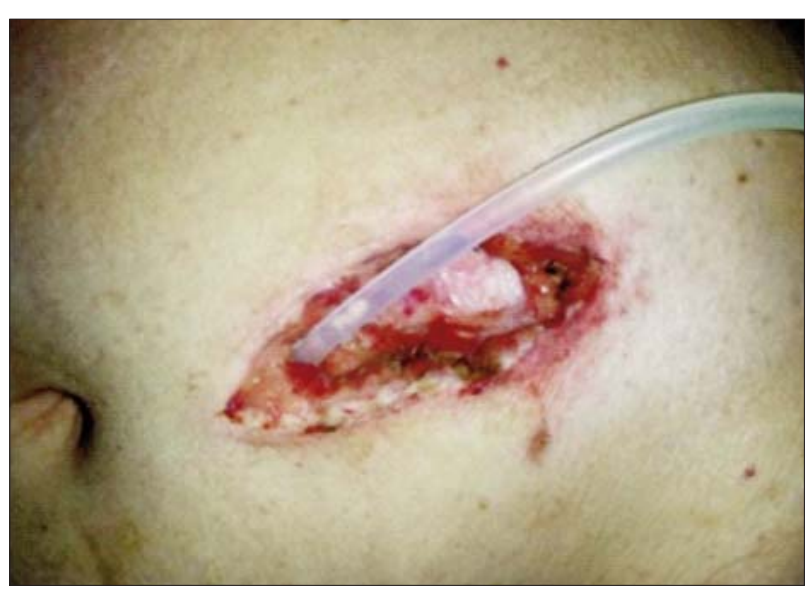

Figure 4. Sunbcutaneous tunnel infection drainage

other two had multisystem organ failure due to prolonged sepsis. 
Comparing the patients with non-infectious with those with infectious complications we found that were no differences regarding mean age, sex distribution, level of education or associated comorbidities like diabetes mellitus, cardio-vascular diseases or neurological disorders. Significant association was found between type of complications and the length of PD in the sense that infectious complications tend to appear later than the non-infectious. Also the loss of peritoneal dialysis is strongly associated with infectious complications (Table 4). Looking inside groups we found that abdominal wall defects are associated with the history of previous abdominal surgery $(p<0,001$ Pearson Chi-square) Regarding the morbidity and mortality only infectious complications had associated mortality in our study, there were no significant differences in morbidity rate between groups.

\section{Encapsulating Peritoneal Sclerosis (EPS)}

In a ten year interval we found 16 cases of EPS. Sex ratio was $9 / 7$ male/female. The mean age of the patients was of $59 \pm 11.1$ years. The median duration of dialysis was of 41 months (range 14 to 136). The number of peritonitis episodes during peritoneal dialysis was more than 3 in 5 patients, between 1 and 3 episodes in 7 patients and in 2 patients, the number of peritonitis episodes could not be established, one patient was at his first episode at the time of the diagnostic and one patient had no peritonitis at all, but instead suffered from a wound and subcutaneous tunnel infection at the time of the peritoneal access. The median duration of hospitalization was of 7 (range 3 to 22). Diabetes mellitus was present in 13 of the 16 patients. The main indication for surgical intervention was peritonitis refractory to treatment (10 cases), the extraction of catheter due to ultrafiltration failure (2 cases), complicated parietal defects (1 case of umbilical hernia and 1 case of incarcerated incisional hernia), bowel obstruction (1 case) and malfunction of the catheter due to it's mobilization (1 case). With two exceptions, the diagnostic has been established at the time of the surgical intervention addressed to other complication or pathology. Two patients were diagnosed with EPS after approximately 5 months after discontinuation of $\mathrm{PD}$, in one of

Table 4. Comparison between infectious and non-infectious complications groups

\begin{tabular}{|c|c|c|c|c|c|}
\hline & & $\begin{array}{c}\text { Infectious } \\
\text { complications } \\
(\mathrm{N}=49)\end{array}$ & $\begin{array}{l}\text { Non-infectious } \\
\text { complications } \\
(n=42)\end{array}$ & $\mathrm{p}$ value & \\
\hline \multicolumn{2}{|l|}{ Age (mean \pm stdv) } & $60,39 \pm 12,9$ & $60,83 \pm 11,8$ & 0,865 & t-test \\
\hline \multirow[t]{2}{*}{ Sex $-2-$} & M & 37 & 28 & 0,352 & Pearson Chi-square \\
\hline & $\mathrm{F}$ & 12 & 14 & & \\
\hline \multirow{3}{*}{\multicolumn{2}{|c|}{ Level of education }} & 16 & 6 & 0.09 & Pearson Chi-square \\
\hline & & 28 & 28 & & \\
\hline & & 5 & 8 & & \\
\hline \multicolumn{2}{|c|}{ Hemoglobin g/dl (mean \pm stdv) } & $10,91 \pm 2$ & $10,69 \pm 1,4$ & 0,561 & t-test \\
\hline \multirow[t]{4}{*}{ Remaining diuresis } & $0-500$ & 16 & 9 & 0,265 & Pearson Chi-square \\
\hline & $500-1000$ & 15 & 19 & & \\
\hline & $1000-1500$ & 2 & 4 & & \\
\hline & $1500-2000$ & 16 & 10 & & \\
\hline \multicolumn{2}{|c|}{ Length of PD in months (median) } & $10(0,75-101)$ & $3,5(0,25-48)$ & $<0,001$ & Mann-Whitney U test \\
\hline \multirow[t]{3}{*}{ Comorbidities } & Diabetes Mellitus & 28 & 23 & 0,820 & Pearson Chi-square \\
\hline & Cardio-vascular diseases & 26 & 14 & 0,090 & \\
\hline & Neurological disorders & 21 & 16 & 0,645 & \\
\hline \multicolumn{2}{|c|}{ Postoperative complications } & 7 & 4 & 0,487 & Pearson Chi-square \\
\hline \multicolumn{2}{|c|}{ Loss of PD } & 40 & 5 & $<0,001$ & Pearson Chi-square \\
\hline
\end{tabular}


these patients at the time of extraction of the dialysis catheter. Intraoperative, the typical aspect of advanced EPS has been identified in 13 cases. This was represented by thickening of the parietal and visceral peritoneum associated with agglutination of the small bowel loops covering thereof by a fibrous membrane (Fig. 5). In two cases the intraoperative aspect was of an incipient EPS -parietal and visceral peritoneal thickening without intestinal obstruction (Fig. 6) and one patient had an abscess with thick walls, situated in the upper part of the peritoneal cavity, which contained the catheter. The surgical intervention consisted of extracting the dialysis catheter, washing and drainage of the peritoneal cavity in all patients. Adhesiolysis with complete release of the small bowel loops was necessary in $8(50 \%)$ of the patients (Fig. 7). An additionally surgical repair of a parietal defect was performed in the two patients. In 12 patients peritoneal samples was taken. Histopathological examination revealed the presence of fibrosis and of inflammation infiltration, however, without being able to provide specific elements. All patients were switched to hemodialysis.

Postoperative evolution has been favourable for all but the 3 cases (20\%) that died. A fourth patient died 2 months after the surgical intervention, from a myocardial infarction so, the death cannot be linked to EPS. Between the rest of three patients 2 died from severe and prolonged unsolved sepsis which lead to multiple organ failure and one from a severe digestive haemorrhage.

\section{Discussions}

\section{Non-infectious complications}

Mechanical complications, mainly peritoneal catheter problems are increasing in relative importance as a cause of technique failure (7). Even if in our initial lot there were 30 patients with ultrafiltatrion failure and only one patient with mechanical complication that lead to PD failure in fact, as many patients fail on $\mathrm{PD}$ as a result of catheter problems as for inadequate dialysis or ultrafiltration failure. Although guidelines do exist and practitioners of PD

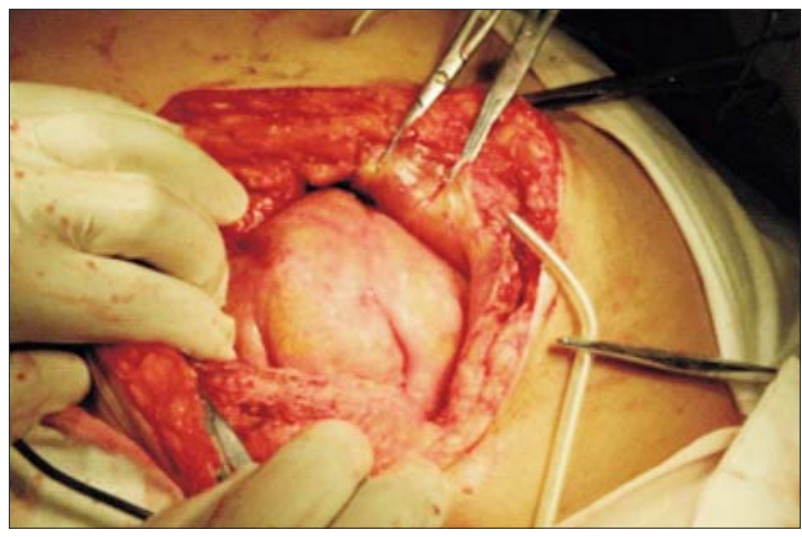

Figure 5. Intraoperative aspect of an advanced EPS - the small bowel loops are agglutinated as in a cocoon

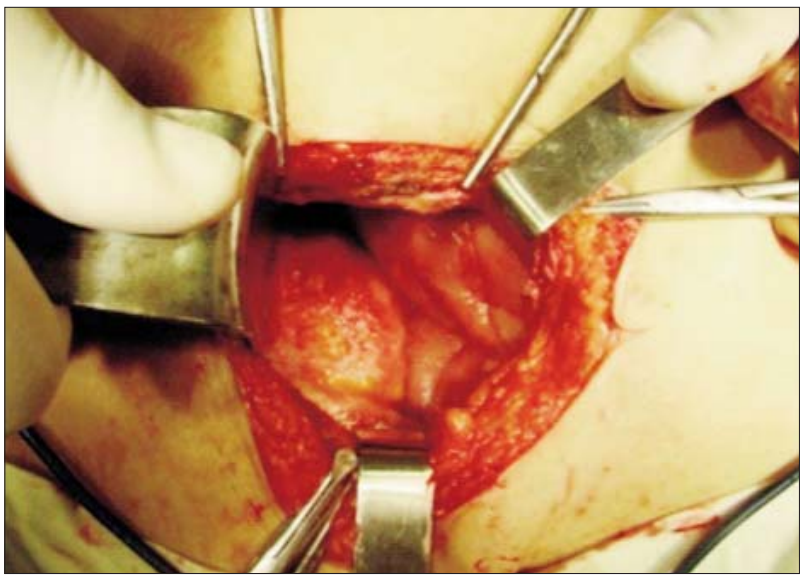

Figure 6. Intraoperative aspect of an incipient encapsulating peritoneal sclerosis

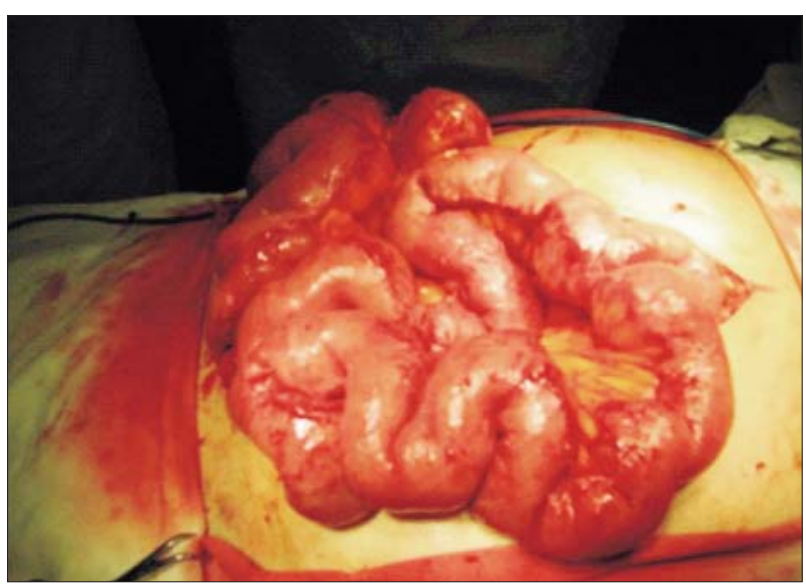

Figure 7. Intraoperative aspect -final aspect after adhesiolysis

should be familiar with them, few multicenter, prospective trials have defined optimal catheter practice (8). 
We could not analyze the relation between the type of the catheter and mechanical complications because we didn $t$ had complete data regarding the type of the catheter. Most of them were straigh cathters and non were „swan neck” type.

Multiple studies were made on different PD catheter design. Overall the "swan neck" catheter has the lowest rate of drainage failure. Intraperitoneal configuration, straight versus coiled, does not seem to modify this risk $(8,9)$. The catheter tip should sit deep in the pelvis. For this an appropriate intraperitoneal catheter length is mandatory. A catheter that is too short will have a poor drainage because the catheter will sit higher in the abdomen being vulnerable to obstruction by the great omentum. Also, preoperative exit-site marking plays a significant role in successful function (10).

Early malfunction of the catheter may be prevented by an appropriate catheter selection, an optimal surgical technique, and a close postoperative care. A good communication between the nephrology and surgical teams is neccesary to make the appropriate decisions before and during insertion so the catheter function to be optimal (7).

Regarding the insertion techniqe in our group with catheter disfunction all were inserted by an open surgical technique and oly one was made laparoscopicaly. Although no method is universally recommended for insertion of PD catheters, Crabtree et al have described advanced laparoscopic management with rectus sheath tunneling, prophylactic adhesiolysis, and prophylactic omentopexy. They have reported a reduction in the rate of catheter flow complications to $<1 \%$ compared with $12 \%$ with standard laparoscopic technique. For patients at higher risk for catheter malfunction as a result of previous complicated abdominal surgery, advanced laparoscopic technique provides the best results in experienced hands (11).

Abdominal wall hernia is a common mechanical complication of peritoneal dialysis (PD), affecting 12\% - 37\% patients in published series.In our study represented $19,9 \%$ of all complicaitons. We found a significant association with previous history of abdominal surgery (pi0,001).

Despite the high prevalence of hernias in patients on PD, relatively few data on the epidemiology of the condition have been published. Most studies describe outcomes after surgical intervention. The effect of hernias and their management on PD technique survival remains poorly characterized in the literature (12).

Hernias can also act to sequester dialysate, thereby leading to unpredictable dialysis clearance and ultrafiltration. Studies have identified a low body mass index with muscle wasting and polycystic kidney disease as risk factors for hernia development $(13,14)$.

Elevations in intra-abdominal pressure from large volumes of dialysate might explain the higher incidence of hernias in PD cohorts than in a general population, but that hypothesis remains controversial: some studies showno association, others observed higher rates of hernia formation with greater pressures $(15,16)$.

Increased intra-abdominal pressure may also cause progressive enlargement of the hernial sac and lead to the significant recurrence rates seen with this pathology. For all those reasons, early surgical repair has been advocated (17).

\section{Infectious Complications}

To ensure the success of the PD program, special attention should be paid to both treatment and prevention of the infectious complications. These are defined as exit-site infections, tunnel infections and peritonitis.

Exit-site infections are characterized by the presence of purulent drainage, with or without erythema of the skin at the catheterepidermal interface. Pericatheter erythema of the skin without purulent drainage is sometimes an early indication of infection. (2) Tunnel infections may present erythema, edema or tenderness over the subcutaneous pathway but is often clinically occult. Seldom, tunnel infections occur alone. They appear usually in the presence of an exit-site infection. Such infections must be treated aggressively, oral antibiotic 
therapy is generally recommended. If an exitsite of tunnel infection is presented in conjunction with peritonitis than the catheter should be removed. Simultaneous removal and reinsertion of the dialysis catheter (with a new exitsite) is feasible in eradicating refractory infections due to $\mathrm{P}$. aeruginosa. Shaving the cuff may be considered an alternative to catheter replacement for tunnel infections in selected cases (2).

In our study 9 patients had exit site or tunnel infections and out of these in two cases catheter was removed the rest benefited by a local treatment with or without replacement of the catheter. Also from the patients with peritonitis 5 of them had associated tunnel or exit site infections. In these cases peritoneal dialysis was interrupted.

Peritonitis in PD patients has important diagnostic, progression and treatment features which separate them from the "classical" surgical peritonitis. (3) The most important clinical sign is the cloudy aspect of the effluent. For the positive diagnostic are necessary 2 of the following 3: cloudy effluent, cell count with white blood cells more than $100 / \mu \mathrm{l}$ and at least $50 \%$ polymorphonuclear neutrophilic cells and positive culture from the dialysate $(5,18)$. All our patients with refractory peritonitis meet the diagnostic criteria, in the other forms indications for catheter removal was established by the nephrologist.

Treatment must be started empirically prior to knowledge of the causative organism. Broad spectrum antibiotics must be administrated intraperitoneal or intravenous. Intraperitoneal administration is superior to IV administration due to the possibility to achieve a higher concentration at the site and a lower toxicity (5). The appropriate treatment should obtain resolution in a few days. Refractory peritonitis is defined as failure of the effluent to clear after 5 days of appropriate antibiotics. This situation should be managed by removal of the catheter to protect the peritoneal membrane. Other indications for catheter removal are: relapsing peritonitis, fungal peritonitis and refractory exit -site or tunnel infections (Table 1 - terminology for peritonitis). In our group the main indication for catheter removal was refractory peritonitis and between these the fungi were the most frequent microorganism.

For the surgeon, the differential diagnosis of refractory and secondary peritonitis is representing the real challenge. This problem must be solved quickly by complete imagistic explorations searching to eliminate intraperitoneal loculated collections or digestive and genital associated pathology. An incorrect diagnostic and a delayed correct treatment may have severe consequences for the patient's outcome. Exploratory laparotomy or laparoscopy is indicated to all patients with persistence of peritonitis signs after or a failure to improve after 5 days of correct antibiotic therapy (3). During the study period we found 5 cases with secondary peritonitis that were not included in the study group. Out of these 2 were treated initially as PD peritonitis and only the surgical exploration revealed the real cause of peritonitis. None of these had of the classical clinical sings of peritonitis and also the imagistic explorations failed to show the real diagnosis.

As in literature in our study infectious complications were strongly associated with PD failure. In $81.6 \%$ of cases with infectious complications catheter was removed and PD interrupted.

Infectious complication prevention is a key step in the peritoneal dialyzed patient management. It is starting with the prescription moment of PD. Internationals Society of Peritoneal Dialysis (ISPD) has elaborated a clinical practice guideline for peritoneal access in 2010. All PD involved practitioners should be familiar with the guideline recommendations. Also ISPD recommendation on prevention and treatment of peritonitis are found in guidelines first published in 1983 and revised seven times, last one in 2016.

\section{Encapsulating Peritoneal Sclerosis}

Our series consists of 16 patients diagnosed with EPS. Due to the fact that the patients come from different dialysis centres, the lack of information regarding the history of peritoneal dialysis or the inexistence of an actualized centralized data base regarding the 
patients with peritoneal dialysis, we could not calculate accurately its incidence or prevalence. Another issue comes from the fact that this pathology is mostly diagnosed intraoperative based on the macroscopic changes this affirmation being confirmed in our cases. With one exception all of our diagnoses were established intraoperative. Most of the times the indication for catheter extraction is set by the nephrologist based on the inefficiency of the peritoneal dialysis or refractory and relapsing peritonitis, with the surgical intervention performed in most cases in the nearest centre and not necessary in specialized ones. In these cases, the imagistic investigations necessary for a correct preoperative diagnosis are missing and the surgeon faces an unknown pathology. An important factor that can lead to under diagnosing of EPS is the surgical intervention which in most cases is resumed to a simple catheter extraction without a minimum exploration of the abdominal cavity. These patients are then switched to hemodialysis and lost to surgical follow up. Because of these reasons we consider mandatory a brief review of the diagnosis and treatment characteristics for encapsulated peritoneal sclerosis.

Encapsulated peritoneal sclerosis is defined by the Ad Hoc Committee of International Society of Peritoneal Dialysis as a clinical syndrome characterized by a persisting intestinal obstruction, intermittent or recurrent associated with peritoneal thickening, sclerosis, calcification or encapsulation with or without the presence of inflammation markers (19).

EPS is an uncommon complication associated with peritoneal dialysis but with a reserved prognostic especially when the diagnostic is set in advanced stages. Its exact etiology is unknown.

The occurrence of EPS is associated with multiple factors. Among these are mentioned the long duration of peritoneal dialysis, repeated episodes of peritonitis, usage of acetate-based dialysis solutions or of hypertonic glucose solutions, usage of in-line bacterial filters or exposure to certain antiseptic substances, such as the chlorhexidine. (20). also there is a series of factors that are not linked to PD found in association with EPS: B-blocking agents treatment, intraperitoneal chemotherapy, autoimmune diseases, intra-abdominal infections (tuberculosis), exposure to talc or asbestos, genetic factors (19-23). Even in our series diabetes mellitus was found in $81.2 \%$ of cases Krote el al. in a Dutch EPS study did not find any relation with development of EPS (23).

Around the globe centres reported a variable incidence ranging between 0.8 and $19.4 \%$ which may be increasing along with the PD duration $(22,24)$. A recent Dutch study showed a decrease in incidence from 0.85 in 2009 to 0.14 in 2014 without a decrease number of patients on PD (25).

The aggression over the mesothelial cells plays an important role in the peritoneal remodelling process. At repeated aggression applied by substances such as the glucose, the mesothelial cells are responding by secreting cytokines are attracting macrophages and fibroblasts $(26,27)$. Peritoneal fibrosis appears as a result of a disrupted repair by sedimentation of fibrin on a denuded mesothelium. This process is more accentuated in young patients, which can determine an earlier onset of EPS modifications (23).

Peritonitis episodes are incriminated in the occurrence of EPS, especially the severe ones or those refractory to treatment, also the sterile peritonitis episodes may suggest the occurrence of EPS. Germs like S. aureus, fungi and/or Pseudomonas sp. are frequently incriminated. Kawanishi et al. performed a study in 2004 and has shown that $25 \%$ of EPS cases were associated with a bacterial peritonitis (22). Peritonitis with S. aureus represents a major risk factor for EPS because coagulase-positive organisms have an enzymatic activity capable of converting the fibrinogen into fibrin, a main component of inter-visceral adherences (28). The relationship between peritonitis and EPS is likely complex. Recurrent infections may contribute to development of EPS and presence of EPS may be associated with greater predisposition to peritonitis. (19). This hypothesis matched our series in which diagnosis was established after treating a refractory or recurrent peritonitis. 
On first appearance, the symptomatology of EPS is often vague and non-specific: nausea, vomiting, fullness, anorexia, weight loss. Fibrotic changes determine not only the capture of the bowel by the encapsulating process, but also the destruction of the myenteric plexus so results impairments to the motility and intestinal absorption function. Insidious at beginning and progressive accentuation of the symptoms is characteristic for EPS. In advanced cases there are present signs of bowel obstruction which are not hard to identify. A differential diagnosis disturbed intestinal motility (adhesions, infections or other intra-abdominal pathology) is required.

The computerized tomography is the most valuable of the imagistic explorations and therefore it is the first recommended investigation (29). Suggestive findings for EPS diagnosis are thickening of the intestinal wall, agglutination of bowel loops, the peritoneal thickening and calcification and loculated ascites (30). The plain abdominal radiography and ultrasound can also be used. The abdominal radiography may find air fluid levels, peritoneal calcifications and dilated small bowel loop while ultrasonography may reveal a characteristic trilaminar appearance of the intestinal wall, but requires peritoneal fluid in situ.

There are no blood or effluent markers specific to diagnosis of EPS, elevated levels of C-reactive protein, anemia, hypoalbuminemia may be found but are nonspecific (29). Recently a prospective analysis of peritoneal effluent had been published. It uncovered that collagen- $\alpha 1$ (I), $\mathrm{Y}^{-}$-actin and Complement factors $\mathrm{B}$ and I were elevated up to five years prior to diagnosis. Orosomucoid-1 and a2-HS-glycoprotein chain-B were elevated about one year before diagnosis, while apolipoprotein A-IV and a1-antitrypsin were decreased compared to controls. So, proteins indicative of inflammatory and pro-fibrotic injury are worthy of further evaluation as diagnostic/prognostic markers (31).

The diagnostic of EPS remains based on clinical suspicion confirmed with, primarily, radiological findings. Laparotomy is the only way to make a definitive diagnostic but it can be associated with considerable morbidity and mortality $(19,29)$.

After a diagnosis of EPS, it is generally accepted that PD should be discontinued, and the patient transferred to hemodialysis. In some patients diagnosis is made only after the discontinuation of PD and also in some cases with EPS less severe, stopping PD may exacerbate the condition (6). Drug therapy with corticosteroids (22), tamoxifen (33), and immunosuppressants (34) has been reported to be beneficial for EPS in a small number of cases. EPS can lead to severe malnutrition so nutrition support is crucial. Total parenteral nutrition, sometimes for a prolonged period of time, forms an integral part of both conservative approach and surgical intervention (19). For severe intestinal obstruction surgical enterolysis is necessary. Mortality after surgical intervention which was as high as $50 \%$, in the past, can be reduced to $4 \%$ in hands of an experienced surgeon. Utilisation of a surgical technique similar to those applied in conventional bowel obstruction involving wide resections and anastomosis may lead to severe complications and death. Basic surgical technique for EPS reported by Kawanishi et al consisted in sharp ablation of the capsules and intestinal adhesions. Using this technique a successfully improvement of the bowel obstruction state was obtained in a series of 50 patients (35).

The overall prognosis of EPS on PD can be poor due to age and associated comorbidities. Reported mortality varies between $26-58 \%$ due to different factors which include: different populations different time periods and the definition of EPS. It is also found that mortality increased with length of time on PD $(22,36)$.

\section{Conclusions}

Noninfectious surgical complications are not raising problems for diagnosis or surgical treatment, but an incorrect treatment may lead to failure of the PD.

Infectious complications and especially peritonitis remains the main cause of method failure. These are generating the highest rates of morbidity and mortality from peritoneal 
dialysis complications.

Even if the immediate surgical intervention for peritonitis related to peritoneal dialysis is usually unnecessary, surgical observation is absolutely mandatory in every case. The absence of a response to the proper medical treatment is an indication for peritoneal cavity exploration inclusive by laparoscopy/laparotomy. Any delay in diagnosis and definitive treatment can lead to loss of peritoneal membrane function and even death of the patient.

Encapsulated peritoneal sclerosis is a rare but serious complication of PD. The risk for developing EPS increases with the duration of PD treatment. No predictive and reliable screening tests especially in the early stages of EPS were found. So, it is important not to underestimate the clinical symptoms, diagnosis being based on a high index of suspicion. The only established basic treatment of EPS is enterolysis of peritoneal adhesions, and time should not be unnecessarily wasted on conservative treatment.

\section{Conflicts of Interest}

The authors declare no conflicts of interests.

\section{Author's Contributions}

All authors have equal contributions.

\section{References}

1. Ghaderian SB, Hayati F, Shayanpour S, Beladi Mousavi SS. Diabetes and end-stage renal disease; a review article on new concepts. J Renal Inj Prev. 2015;4(2):28-33.

2. Li PKT, Szeto CC, Piraino B, Bernardini J, Figueiredo AE, Gupta A, Johnson DW, Kuijper EJ, Lye WC, Salzer W, Schaefer F, and. Struijk DG. Peritoneal dialysis - related infections recommendations: 2010 update. Perit Dial Int. 2010;30(4):393-423.

3. Patrascu T, Buga C. Peritoneal Dialysis in Popescu I. (coord.). Textbook of Surgery. Bucuresti: Ed. Academiei Române, 2008; p:1044-1056.

4. Akoh JA. Peritoneal dialysis associated infections: An update on diagnosis and management. World J Nephrol. 2012;1(4):106-22.

5. Li PKT, Szeto CC, Piraino B, de Arteaga J, Fan S, Figueiredo AE, et al. ISPD Peritonitis recommendation: 2016 update on prevention and treatment. Perit Dial Int. 2016;36(5):481-508.

6. Brown EA, Bargman J, van Biesen W, Chang MY, Finkelstein F0, Hurst $\mathrm{H}$, et al. Length of time on peritoneal dialysis and encapsulating peritoneal sclerosis - Position paper for ISPD: 2017 update. Perit Dial Int. 2017;37(4):362-374.

7. McCormick BB, Bargman JM. Noninfectious Complications of
Peritoneal Dialysis:Implications for Patient and Technique Survival. J Am Soc Nephrol 2007;18(12):3023-3025,

8. Flanigan M, Gokal R. Peritoneal catheters and exit site practices towards optimum peritoneal access: A review of current developments. Perit Dial Int 2005; 25(2):132-139.

9. Johnson DW, Wong J, Wiggins KJ, Kirwan R, Griffin A, Preston J, et al. A randomized controlled trial of coiled versus straight swan-neck Tenckhoff catheters in peritoneal dialysis patients. Am J Kidney Dis. 2006;48(5):812-821.

10. Crabtree JH, Burchette RJ, Siddiqi NA. Optimal peritoneal dialysis catheter type and exit site location: an anthropometric analysis. ASAI0 J. 2005;51(6):743-747.

11. Crabtree JH, Fishman A. A laparoscopic method for optimal peritoneal dialysis access. Am Surg 2005;71:135-143.

12. Balda S, Power A, Papalois V, Brown E. Impact of hernias on peritoneal dialysis technique survival and residual renal function. Perit Dial Int. 2013; 33(6):629-634.

13. del Peso G, Bajo MA, Costero O, Hevia C, Gil F, Diaz C, et al. Risk factors for abdominal wall complications in peritoneal dialysis patients. Perit Dial Int 2003; 23(3):249-54.

14. O'Connor JP, Rigby RJ, Hardie IR, Wall DR, Strong RW, Woodruff PW, et al. Abdominal hernias complicating continuous ambulatory peritoneal dialysis. Am J Nephrol. 1986;6(4):271-4.

15. Durand PY, Chanliau J, Gamberoni J, Hestin D, Kessler M. Routine measurement of hydrostatic intraperitoneal pressure. Adv Perit Dial. 1992;8:108-12.

16. Bargman JM. Complications of peritoneal dialysis related to increased intraabdominal pressure. Kidney Int Suppl. 1993;40: S75-S80.

17. Afthentopoulos IE, Panduranga Rao S, Mathews R, Oreopoulos DG. Hernia development in CAPD patients and the effect of $2.5 \mathrm{~L}$ dialysate volume in selected patients. Clin Nephrol. 1998; 49: 251-7.

18. Brook NR, White SA, Waller JR, Nicholson ML. The surgical management of peritoneal dialysis catheters. Ann R Coll Surg Engl. 2004;86:190-195.

19. Kawaguchi Y, Kawanishi H, Mujais S, Topley N, Oreopoulos DG. Encapsulating peritoneal sclerosis: Definition, etiology, diagnosis and treatment. Peritoneal Dialysis International 2000;20(S4): S43-S55.

20. Habib AM, Preston E. and Davenport A. Risk factors for developing encapsulating peritoneal sclerosis in the icodextrin era of peritoneal dialysis prescription. Nephrol Dial Transplant 2010;25(5): 1633-1638.

21. Kawaguchi $\mathrm{Y}$, Saito A, Kawanishi $\mathrm{H}$, et al. Recommendations on the management of encapsulating peritoneal sclerosis in Japan, 2005: Diagnosis, predictive markers, treatment, and predictive measures. Perit Dial Int. 2005;25(S4):S83-S95.

22. Kawanishi H. Kawaguchi $Y$. Fukui et al. Encapsulated peritoneal sclerosis in Japan: a prospective, controlled multicenter study. Am J Kidney Dis. 2004; 44(4):729-737.

23. Korte MR, Sampimon DE, Lingsma HF, Fieren MW, Looman WNC, Zietse $R$, et al. Risk factors associated with encapsulating peritoneal sclerosis in Dutch EPS study. Peritoneal Dialysis International 2010;31(3):269-278.

24. Brown MC, Simpson K, Kerssens JJ and Mactier RA. Encapsulating Peritoneal Sclerosis in the New Millennium: A National Cohort Study. Clin J Am Soc Nephrol. 2009;4(7):1222-1229.

25. Betjes MGH, Habib SM, Boeschoten EW, Hemke AC, Struijk DG, Westerhuis R, et al. Significant Decreasing Incidence of Encapsulating Peritoneal Sclerosis in the Dutch Population of Peritoneal Dialysis Patients. Perit Dial Int. 2017;37(2):230-234.

26. Habib SM, Abrahams AC, Korte MR et al. T-helper cells and fibrosis associated macrophages dominate the peritoneal inflammatory infiltrate in EPS patients. Nephrology Dialysis Transplantation 2013; 28(S1):i5-i7.

27. Kokubo S, Sakai N, Furuichi K, Toyama T, Kitajima S, Okumura T, 
et al. Activation of p38 mitogen-activated protein kinase promotes peritoneal fibrosis by regulating fibrocytes. Perit Dial Int. 2012; 32(1):10-9.

28. Szeto CC, Chow KM, Kwan BCH, Law MC, Chung KY, Yu S, et al. Staphylococcus aureus Peritonitis Complicates Peritoneal Dialysis: Review of 245 Consecutive Cases. Clin J Am Soc Nephrol. 2007; 2(2): 245-251.

29. Brown EA, van Biesen W, Finkelstein FO, Hurst $H$, Johnson DW, Kawanishi $\mathrm{H}$, et al. Length of time on peritoneal dialysis and encapsulating peritoneal sclerosis: position paper for ISPD. Perit Dial Int. 2009;29(6):595-600.

30. Tarzi RM, Lim A, Moser S, Ahmad S, George A, Balasubramaniam $G$, et al. Assessing the Validity of an Abdominal CT Scoring System in the Diagnosis of Encapsulating Peritoneal Sclerosis. Clin J Am Soc Nephrol. 2008;3(6):1702-1710.

31. Zavvos V, Buxton AT, Evans C, Lambie M, Davies SJ, Topley N, et al. A prospective, proteomics study identified potential biomarkers of encapsulating peritoneal sclerosis in peritoneal effluent. Kidney
International 2017;92(4):988-1002.

32. Kawanishi H, Morrishi M. Encapsulated peritoneal sclerosis: prevention and treatment. Perit Dial Int. 2007; 27 (S2): S289-S292.

33. Korte MR, Fieren MW, Sampimon DE, Lingsma HF, Weimar W, Betjes MG, et al. Tamoxifen is associated with lower mortality of encapsulating peritoneal sclerosis: results of the Dutch Multicentre EPS Study. Nephrol Dial Transplant. 2011;26(2):691-7.

34. Lafrance JP, Letourneau I, Ouimet D, Bonnardeaux A, Leblanc M, Mathieu N, et al. Successful treatment of encapsulating peritoneal sclerosis with immunosuppressive therapy. Am J Kidney Dis. 2008; 51(2):7-10.

35. Kawanishi H, Watanabe H, Moriishi M, Tsuchiya S. Successful surgical management of encapsulating peritoneal sclerosis. Perit Dial Int. 2005;25(S4):S39-S47.

36. Summers AM, Clancy MJ, Syed F, Harwood N, Brenchley PE, Augustine $\mathrm{T}$, et al. Single-center experience of encapsulating peritoneal sclerosis in patients on peritoneal dialysis for end-stage renal failure. Kidney Int. 2005; 68(5):2381-8. 